\title{
Federal Shariat Court an Intrigue Un-raveled
}

\author{
Dr. Parvez Ahmed, Dr. Syed Mussawar Hussain Bukhari, \\ Associate Professor of Political Science, Govt. Emerson Post Graduate College, Multan. \\ Department of Political Science, The Islamia University of Bahawalpur, \\ Pakistan \& Adjunct Fellow of MAI, AU.
}

\begin{abstract}
From the first address of General Zia, it was clear that he would use the name of religion for the safety and lengthening of his dictatorial rule. He was ready to use the Pakistan National Alliance Movement for his personal rule. He overthrew the elected government of Bhutto with the consultation of his coterie and on the popular public demand. After acquiring power, Zia forget his promise of holding elections within 90 days which was also a constitutional requirement and began to take steps to sabotaging the election process. In this process he got success and postponed the elections for an indefinite period in the name of accountability. After this he took some steps towards the implementation of Islamic system to legitimize his rule. Zia, to legalize his government both on internal and external fronts used the name of Islam and the set up of (Islamic)Shariat Benches. The set up of Shariat Benches was one of the steps which left indelible imprints on the political system and particularly on the judicial system of Pakistan. Though, he established the Shariat Benches as a first step towards the implementation of Islamic system yet he used these benches to pressurize the judiciary for making service rules for this set up.
\end{abstract}

\section{ESTABLISHMENT OF SHARIAT BENCHES}

The intention of General Zia behind the creation of Federal Shariat Court is seen as the forum to pressurize the traditional judiciary and gaining favor for his dictatorial regime. Ever since its establishment, the Federal Shariat Court is a mode of controversy in the minds of democratic people but the military dictator created institution according to the needs of time and strengthening his absolute power. The establishment of Shirat Benches was announced on the first of Moharram 1978 as a part of enforcement of Islamic system. These Shariat Benches started their working in 1979. During this period, Supreme Court had validated the imposition of Martial Law, the political parties were banned, censorship was imposed, Bhutto was hanged and some of the Pakistan National Alliance parties had joined Zia regime. So the military regime felt no hesitation in introducing their reforms.

According to the Constitutional Amendment Order 1979, a Shariat Bench was to be set up at each high court and a Shariat Appellate Bench in the Supreme Court. Their function was to declare the existing laws invalid if they were repugnant to the Holy Quran and Sunnah. Zia stated that the religious courts were meant to supplement not to replace the conventional system. By establishing the Shariat Benches, Zia killed two birds with one stone. He fulfilled the wishes of Ulema as well as managed to create soft corner for his government in the minds of the masses. Already Zia had promised the nation for the enforcement of Islamic system in his address on $5^{\text {th }}$, July 1977 upon the promulgation of Martial Law. "I must say that the spirit of Islam, demonstrated during the recent movement was commendable. It proved that Pakistan, which was created in the name of Islam, would continue to survive only if it sticks to Islam. I consider the introduction of Islamic system as an essential pre requisite for the country." Establishment of Federal Shariat Court was the response of the 1977 Movement led by Pakistan National Alliance against Z.A.Bhutto government. General Zia got opportunity to exploit the simple Minded people of the country as well as religious leaders and used the institution for his ulterior motives.

Mulana Maudadi described this step, "as a land mark in the history of the country." Mufti Mehmood named "The Shariat Bench Order as a land mark in the enforcement of Nizam -e- Mustafa." Mian Tufail Mohammad stressed and suggested that the provisions relating to the Shariat Benches must be incorporated in the constitution of 1973. Religious parties and other religious minded people all over the country praised General Zia on this implementation. Now a big class of his supporters had been produced which was becoming a large power-base for him and his regime. Zia accepted the suggestion from the religious leaders and amended the constitution by adding the Shariat Benches as Chapter 3-A, of the constitution. This induction in constitution could be called a great success of religious parties and common people who had great inclination to religion, Islam. While pacifying the masses he used this amendment very tactfully in favour of his government. He played game very silently with public, constitution, superior judiciary and religious parties by excluding the basic institutions from its jurisdiction. These important laws having been excluded from the jurisdiction of the benches are as follow; 
1- Constitution

2- Muslim Personal Law

3- Procedure of a court or Tribunal

4- Any Fiscal Law

Though with the exclusion of the above laws from the jurisduction of Benches, government protected its position yet there was no constitutional guarantee for Shariat Benches to continue permanently. Their continuation depended on the will of the coming government or the elected government, whenever the elections were to be held. Nobody knew about the holding of elections which were pledged by Zia on the imposition of Martial Law .For encouraging the making of Shariat Benches, Religious parties' leadership pressurized Zia for the establishment of Qazi courts to district level under the supervision of Federal Shariat Court but the bullet slipped away close to the ear. In response, Zia established the Federal Shariat Court as parallel hierarchy in the existing judicial system. He set up the federal Shariat Court after one year's establishment of Shariat Benches by amending the constitution of 1973. The court was set up with powers to declare invalid any law or provision of the law as repugnant to the injunctions of Islam as laid down in the Holy Quran and Sunnah of the Holy Prophet (pbuh]. It had a revision cum appellate jurisdiction; it could examine the record of any case decided by any court relating to the enforcement of Hadood, for determining the correctness of the court findings.

He defaced the 1973 Constitution by wearing the mask of religion and by amending those provisions of the constitution which could favour his personal rule. He weakened the traditional judiciary just for his personal satisfaction. The superior judiciary was under a cloud due to the introduction of structural changes in their constitutional safeguards. It was to pressurize the judiciary; even though such powers had been conferred only a year earlier on Shariat Bench of High Courts under the Constitutional Amendment Orders 1979. . It was a major blow to our judiciary by the hands of a Military dictator. Before the establishment of this parallel court, the high court vested the powers by the constitution of 1973 for the checking of laws repugnant to the holy Quran and Sunnah. It is clear as day light that injunctions of Islam, as laid down in the Holy Quran and Sunnah of the Holy Prophet (pbuh) are the supreme laws of Pakistan ever since the Objective Resolution of 1949. There was no need of Federal Shariat Court to judging the law repugnant to the Quran and Sunnah. Thus the 1973 Constitution already provided the institution of Islamic Ideology Council for this purpose and it was fulfilling its described and prescribed duties. He declared his no confidence in the wisdom and power of the judiciary, although the judiciary in Pakistan had almost always obliged the rulers. The intention behind the creation of Federal Shariat Court is seen as the forum to pressurize the judiciary and gaining favor for his government. Ever since its establishment, the Federal Shariat Court has been the subject of criticism and controversy in the society.

\section{COMPOSITION OF FEDERAL SHARIAT COURT}

The federal Shariat Court, established for gaining personal benefits, by a military dictator was to consist of five members, including the chairman, who was to be a judge of High Court or Supreme Court of Pakistan, who was to be appointed by the president. Moreover the Federal Shariat Court judges were to hold office only at the discretion of the president rather than under the constitutional structure of 1973 Constitution fixed for the superior judiciary. It was a direct attack on the service structure of the judges of superior judiciary but hidden motive was to undermine the judicial institution in the name of public demand. So the enclosed message conveyed to judiciary was that, if it did not go with the military dictator, the government would send them home. The president was empowered to send a High Court judge to the federal Shariat Court without his consent. If he refused to accept appointment as a member of federal Shariat Court, he would be deemed retired from his office. "His (Zia) acts come under the mischief of Islamic Law." The judges of federal Shariat Court were to be appointed and removed on the sweet will of the president. He could assign the judge any other office or require of him to perform such other functions as the president might deem fit. At this critical juncture, the judges of superior judiciary should have reacted very severely against the change of structure which was provided by the constitution of 1973 and were guaranteed of independent and neutral dispensation of justice. This service structure was the safeguard of neutrality and fair functioning. Now the fate of judges was in the hands of a military dictator and he was ready to use the instrument of Federal Shariat Court judges according to the needs of his government. The appointment and transfer of the federal Shariat Court judges depended on the discretion of the president only. It was the president who could fix their remunerations and could appoint them any where, to any post of that pay scale. The refusal to accept the appointment meant despair from judgeship. This meant that the judiciary stood with folding arms before the dictator, and the public at large, had accepted the regime of terror. It was obvious that the Judiciary alone couldn't resist the executive because the judges of Pakistan were often weak due to the flaws in appointment process and also due to the absence of public support. The judiciary had lost public support mainly because it had always made its decisions under the Law of Necessity. 
It was the dilemma of this parallel judicial system that in 1980, Mr Justice Aftab Hussain of Lahore High Court was transferred to the Federal Shariat Court without any cause or his consent. Though, he had cooperated with Zia government in the judgment of Muhammad Ahmad Khan's murder case. "Earlier he had, coerced the judiciary into cooperation and was able to get Bhutto hanged." Yet Zia did not spare him. "Thus a federal Shariat Court consisting of hand picked judges by the president was set up as a super constitution". Since the services of the judiciary were in the hands of the executive, it was very difficult for them to decide cases on merit. There have been a few judges in the history of Pakistan who resisted the executive. This includes A.R. Cornealous, Drob Patel, S.M. Samadani and a few others. Justice S.M.Samdani told the Chief Martial Law Administrator during a meeting that the military bureaucracy was equally responsible for the social evils as the civil bureaucracy. Solace through justice is a very difficult task, which demands independence, mental peace and security of job. All these were snatched from judiciary by the undemocratic and democratic forces. One can see the reaction of rulers specially of a dictator to any judicial decision which he thinks is not according to his Wishes. The reaction of General Zia on the decision of Federal Shariat Court is a classical example of the madness of the dictator. The first Chief Justice of Federal Shariat Court Justice (retired) Salahuddin Ahmad wrote the judgment on adultery. He followed the liberal view of Islamic scholars and held that Islamic law did not support stoning to death in case of adultery. It roused the wrath of Zia-ul-Haq and the religious parties against the judgment. President. Zia mixed religion and politics by making the parallel institution of Federal Shariat Court. "Zia painted the stracture of justice in a new and controversial colour under the cover of Federal Shariat Court." General Zia-ul-Haq made a public statement that the courts (judiciary) were frustrating his program of Islamization. How can we evaluate the complete role of any institution on one of his acts? It could be a risk for personal interests not for the public interest. General Zia was waiting for the right moment for striking the judiciary which he got in 1981 on introducing the Provisional Constitutional Order. President Zia granted appellate and the revision powers to Federal Shariat Court under the 1981 Provisional Constitutional Order. Now the position of Federal Shariat Court became stronger due to appellate and revision powers, which other wise were dealing with abstract and academic controversies and questions. The High courts lost their appellate powers in criminal cases, which they were using from the inception of High Courts. The judgment on adultery by the first Chief Justice of the Federal Shariat Court was revised and set aside by the new Chief Justice, Aftab Ahmad. The court was empowered to review its decisions as a face saving device. General Zia got the decision as he wanted by giving the revision powers to the Federal Shariat Court, though the appellate court was there in the form of Supreme Court. This forum was used because the forum of Supreme Court could not be pressurized as easily as that of Federal Shariat Court. The fate of judges of Federal Shariat Court was in the hands of the president so it was an easy task for the dictator to gain favourable decisions and he succeeded in it. Under the Provisional Constitutional Order three Ulemas were introduced to the court in addition to five judges.The appointment of three Ulema judges in Federal Shariat Court was a great crafty handling of military dictator for favourable feelings in the court. He appointed the Ulema as judges in the Federal Shariat Court who had no legal training or regular legal knowledge. These newly appointed Ulema Judges were given standing on equal footing with High Court judges who had long legal career. Zia put the judiciary under pressure and introduced new hierarchy in the form of the Federal Shariat Court. The Ulema Judges were under the obligation of government in one or the other way. Their job was too purely dependent on the sweet will of the president. It asserted a continuous pressure on the superior judiciary by the executive to gain favor in their decisions because superior judiciary was the only constitutional institution which could create hurdle in the unconstitutional and illegal actions of the dictator. All other institutions of the state were directly running under the sole control of the military dictator In this context Benazir Bhutto said that she believed in the Holy Quran and Sunnah bestowed upon them by Almighty Allah but not in the supremacy of Federal Shariat Court.

Benazir Bhutto in her second term launched her decisive plan to dominate the judiciary and to use the Federal Shariat Court as a tool. She appointed Justice Mahboob Ahmed Chief Justice Lahore High Court as a judge of Federal Shariat Court. He refused to take up the new office and opted retirement before time. He was the senior most judge of Lahore High Court and should have been sent to Supreme Court but the government attempted to sideline him due to his opposition in the appointment of Pakistan Peoples Party workers (lawyers) as new judges in Lahore High Court. She achieved her objective after his retirement.

Justice Mohd Ilyas of Lahore High Court was sent to federal Shariat Court as a judge without his consent. He was punished by the government for his attachment with the opposition. The high court bar also opposed this appointment. "I have been treated very unfairly, he told Sajjad Ali Shah, chief justice of Pakistan Benazir government and PPP was hankering to dominate the judiciary as if they had not learnt any lesson from the past experiences with courts. She wanted to appoint her party loyal lawyers as judges at any cost. She sent Nasir Aslam Zahid chief justice Sindh High Court to Federal Shariat Court to adjust Abdul Hafeez Memon as Chief Justice of Sindh High Court. He had the record of having been sworn as a judge six times. Nasir Aslam Zahid had been a hurdle in the appointment of pro Pakistan Peoples Party judges in the Sindh high court. "In, the past, this court was used as a refuge for the recalcitrant judges." The new chief justice recommended the pro 
P.P.P (Pakistan Peoples Party) lawyers for appointment as judges to Sind High Court. "Nasir Aslam Zahid was consigned to the Shariat Court because of his non-cooperative attitude." It is minutely observed that this court merely duplicates the functions of the existing superior courts and almost every government used this court more or less as a pressure tool to achieve its objectives. The composition of the court, particularly the mode of appointment of its judges and the insecurity of their tenure reflects that this court does not fully meet the criteria prescribed for the independence of superior judiciary. So due to these reasons this court is not in a position to bore the pressures and influence inflicted from the executive.

\section{CONCLUSION}

Military dictator made new amendments in the constitution for personal gains and strengthening and lengthening of the personal rule. Islamization of laws and establishment of Federal Shariat Court were his tactics to control the superior judiciary. He mobilized a class of so called Ulema, and established courts for them in the name of Islamization. He believed in the form rather than the spirit of Islam. Zia painted the structure of justice in a new and controversial color under the cover of federal Shariat Court Zia quaintly mixed religion and politics by making the institution of Federal Shariat Court. He made and used this institution for strengthening his power, and to obtain the political support of religious people and parties. He made the judiciary docile to his ill will by introducing a parallel court. The judges of Federal Shariat Court were judges only with the sweet will of the president otherwise they could be posted to any office where deemed fit. The president's wish prevailed since the judges of Federal Shariat Court had no constitutional guarantees. Ironically the governments after Zia used this institution for pressurizing the judiciary and gained their personal and party objectives. Benazir Bhutto was one of them who used Federal Shariat Court for party's objectives.

\section{REFERENCES}

[1]. PLD 1980,Central Statute ,p.89(Constitution Amendment Order,1980)Vol.xxxii

[2]. T.V. Speech Chief Martial Law Administrator General Zia ul Haq, 5th July 1977

[3]. Munir, Muhammd Justice Retired, From Jinnah to Zia, Vanguard Books, Ltd., Lahore, p. 141

[4]. PLD 1979,Central Statute,pp-31-32,Vol,xxix(Inserted chapter 3-A in constitution of 1973)

[5]. PLD 1979,Central Statute,p.6,Vol,xxix( Section 2(a)) Munir, Muhammd Justice Retired, op-cit, p.141

[6]. Zahoor,Tanveer, Aihad Saaz Mounsaf Justice (R)Nasim Hasan Shah, Alhamad Publications ,Leek Road ,Lahore, 1997,pp.75-76 Ibid. pp.75-76

[7]. Iqbal,Javaid,Dr. Justice, Apna Granban Chaak, Sange-e-maeel publications, Lahore, 2003, p.211

[8]. Ali, Shoukat Sardar, Pakistan Issues and Politics, Fixation House Lahore, 2003, p. 159

[9]. Mehmood, Safder, Dr. A Political Study of Pakistan, Sang-e-mel Publications, Lahore,1987,pp.245-246(Objective Resolution 1949-Origional Text) Dawn, Karachi, $6^{\text {th }}$ October, 1988

[10]. Paula,R.Newberg, Judging The State Courts, Cambridge University Press,New Delhi, $1995, \mathrm{p} .242$

[11]. PLD 1980,Central Statute,VOL.xxxiii,p.91(Article 203-C-A, The Constitution of 1973)

[12]. Shah, Hasan, Nasim(Retired)Justice, Memories and Reflections, Alhamara Publishing Company,Islamabad,2000,p.150 Ibid,(Article 203-C-5, The Constitution of 1973)

[13]. The Pakistan Times, Lahore, 25 ${ }^{\text {th }}$ July 1990(Article 203-C, The Constitution of 1973) The Frontier Post,Peshwar, $17^{\text {th }}$ August 1992

[14]. Khan,Hamid, Constitutional And Political History Of Pakistan, Oxford University Press,Karachi,2004,p.638 Ali Shoukat Sardar, op-cit, p.139 Ibid, p. 140

[15]. The Frontier Post, Peshawar,17th August 1992

[16]. Samdani, M.K. (Rtd) Justice, Jaiza , Sang-e-Meel Publications Lahore, 2004, p.77 PLD 1981, Federal Shariat Court, p. 145 (Hazoor Buksh VS Federation of Pakistan) Paula,R.Newberg, Op-cit,p.242

[17]. Patel,Drob,Testament of Liberal,Oxford University Press,Karachi, p.164-165

[18]. PLD 1983, Federal Shariat Court, p.255 (Federation of Pakistan VS Hazoor Baksh)

[19]. PLD 1981, Central Statute, p. 251(President's Order 5 of 1981)PLD Vol.xxxiii

[20]. Yasin, Muhammad, Bunari,Tariq, The Disensation of Justice in Pakistan, Oxford University Press, Karachi,2004,p.81

[21]. The Frontier Post, Peshawar, 12 ${ }^{\text {th }}$ August 1992 Mian,Ajmal,(Former Chief Justice of Pakistan)A Judge Speaks Out, Oxford University Press,Karachi,2004,p.163

[22]. Jang,Sunday Magazine, Lahore, $6^{\text {th }}$ Novomber 2005(Interview Justice Retired Mahboob Ahmed)

[23]. Shah Ali Sajjad, Law Courts in A Glass House, Oxford University Press Karachi, 2001, pp. 199-200

[24]. Ibid, p. 199

[25]. Dawn, Karachi, $9^{\text {th }}$ November, 1997

[26]. Jalal,Ayesha (Edited), The Oxford Companions To Pakistani History, Oxford University Press Karachi, 2012, p. 166

[27]. Arif,Mehmood, Khalid, Khaki Shadows, Oxford University press, Karachi, 2001, p.311 